\title{
The First Record of the Hooded Pitta Pitta sordida from Japan
}

\author{
Takashi Hiroaka*
}

The Hooded Pitta Pitta sordida, with 13 subspecies, ranges from Himalayas, northwestern India, Indochina, and Malay Peninsula to Greater Sundas, Philippines, and New Guinea (Traylor 1979). There have been no record of this species from Japan except one from Ryukyu Islands which this article deals with.

On June 1, 1984, an individual of this species was seen chased by a Jungle Crow Corvus macrorhynchos and struck a window of Heishin Elementary School, Ishigakicity $\left(24^{\circ} 20^{\prime} \mathrm{N}, 124^{\circ} 10^{\prime} \mathrm{E}\right)$, Okinawa Prefecture. It was caught alive and kept by $\mathrm{Mr}$. Osamu Shimamura until it died on June 6, 1984 (Shimamura pers. comm., Sonobe 1986, Anon. 1988). Mr. Shimamura fed it on earthworms Opisthopora, cockroaches Blattariae, grasshoppers Caerifera, phasmids Phasmida, etc. The bird seemed to like earthworms best (Shimamura pers. comm.).

The description of this specimen is as follows. Forehead, crown, and nape brown. Lores, cheeks, chin, throat, and a collar surrounding the nape black. Mantle, back, and scapulars green. Upper tail-coverts and lesser wing-coverts shiny light blue. Tail black, tipped with dull blue. Breast, flanks, and upper belly paler green with a slight light-bluish sheen. No black patch of central belly. Lower belly and under tailcoverts rosy red. Greater and median coverts green, slightly brighter than back. Alula and primary coverts black. Primaries black, with white parts on the 4th to 10th primaries, forming a white patch in the wing. Secondaries black with greenish margins on outer webs. Tertials with both inner and outer webs dull greyish green. Under wing-coverts black.

Measurements (mm): wing (left) 116 (maximum length), exposed culmen 20.7, tarsus 38.9 , tail 36.8 .

Of the 13 subspecies, only the subspecies cucullata has the entire crown brown, while two of the rest, abbotti and bangkana, have black median stripe on the crown, and the other 10 have the entire head black (Sclater 1888, Baker 1926, Delacour 1947, duPont 1971, Rand and Gillard 1967).

The crown, and other features of the specimen agree with the description of the subspecies cucullata. The measurements fall within those of this subspecies given by Baker (1926), except the tail. Thus I conclude this specimen belongs to the subspecies cucullata.

This subspecies breeds in Himalayas, north-western India, and Indochina, part of the population wintering in Malay Peninsula, Sumatra, Java, and neighbouring islands. According to King and Dickinson (1975) it inhabits northern Laos and southern Vietnam,

Received 4 July 1989, accepted 21 August 1989

* Yamashina Institute for Ornithology, Konoyama, Abiko, Chiba, 270-11 Japan 

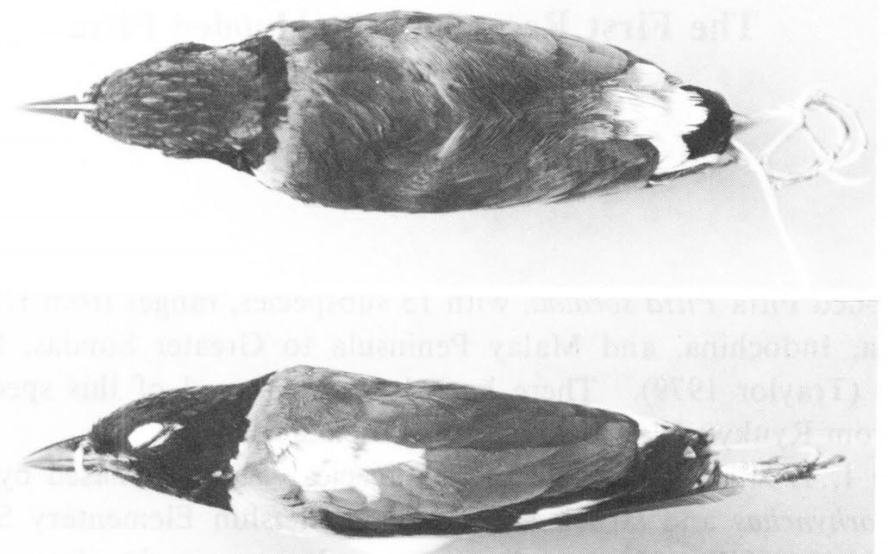

Fig. 1. The specimen of the Hooded Pitta Pitta sordida from Ishigaki-city.

not including central and northern Vietnam. Although cucullata is recorded also from China, it is unlikely that its range in China stretches far from south-eastern Yunnan, because both Cheng (1958) and de Schauensee (1984) refer only to Mengtzu in southeastern Yunnan as its locality in China.

So the known locality of cucullata closest to Japan is northern part of Laos to southeastern Yunnan, which is more than $2000 \mathrm{~km}$ west of Ishigaki Island. On the other hand, the closest normal range to Japan of the species as a whole is the Philippines which is some $900 \mathrm{~km}$ south of Ishigaki Island. In the Philippines there lives a black-crowned subspecies sordida. It seems rather unusual that a bird was recorded from far east of its normal range in the breeding season, and it was not the subspecies of the closest locality.

But I did not find on this specimen any sign of long captivity, such as unusual development of the upper mandible, swellings in the feet, or wear of feathers, although the tips of some longer primaries were a little broken, which may have been caused when the bird struck the window or thereafter.

Considering the range of this subspecies there may still be a possibility that this individual was brought to Japan by some human activity.

I would like to thank Mr. Osamu Shimamura who donated this rare bird to Yamashina Institute, with valuable information. Thanks are also due to the staff of the Wild Bird Society of Japan for the efforts made concerning this donation. I express thanks to Dr. Nagahisa Kuroda for the comments and advice on this report.

\section{References}

Anon. 1988. Birds that flew to Japan. Yacho, 53(4): 10-21. (in Japanese).

Baker, E. C. S. 1926. The Fauna of British India including Ceylon and Burma. Birds. vol. III. 2nd ed. Taylor and Francis, London, 489 pp. 
Cheng, Tso-hsin. 1958. A Distribution List of Chinese Birds. II. Passeriformes. Science Pubilshing House, Peiping. 352 pp.

Delacour, J. 1947. Birds of Malaysia. The Macmillan Company, New York, 382 pp.

de Schauensee, R. M. 1984. The Birds of China. Oxford University Press, Oxford. 602 pp.

duPont, J. E. 1971. Philippine Birds. Delaware Museum of Natural History, Greenville. 480 pp.

King, B. E. \& Dickinson, E. C. 1975. A Field Guide to the Birds of South-East Asia. Collins, London. $480 \mathrm{pp}$.

Rand, A. \& Gillard, E. T. 1967. Handbook of New Guinea Birds. Weidenfield and Nicholson, London. $612 \mathrm{pp}$.

Sclater, P. L. 1888. Catalogue of the Birds in the British Museum. vol. XIV. Taylor and Francis, London. $494 \mathrm{pp}$.

Sonobe, K. 1986. New Hints on Bird Identification. 11. Yacho, 51(4): 6 (in Japanese).

Traylor, Jr., M. A. (ed). 1979. Check-list of Birds of the World. Museum of Comparative Zoology, Cambridge. 365 pp.

\section{ズグロヤイロチョウ Pitta sordida の日本初記録}

1) 1984 年 6 月 1 日, 沖縄県石垣市内でズグロヤイロチョウが保護され，同月 6 日死亡した。

2)当該標本の羽装の特徵を調べ各部の計測をおこなった。

3）上記 2 より, 本個体は亜種 P.s. cucullata と判断した。

4) 亜種の分布地域を考慮すると，本個体は人為分布の可能性もある。

平岡 考：山階鳥類研究所, 于270-11 我棌子市高野山 